УДК: 378.017.4:37.091.212

DOI:

Оксана Васюк, доктор педагогічних наук, професор, професор кафедри педагогіки Національного університету біоресурсів і природокористування України

Світлана Виговська, кандидат педагогічних наук, дочент, доцент кафедри педагогіки Національного університету біоресурсів і природокористування України

Андрій Зв'ягельський, студент магістратури Наиіонального університету біоресурсів і природокористування України

\title{
ДОСЛІДЖЕННЯ ПАТРІОТИЗМУ В СТУДЕНТСЬКОЇ МОЛОДІ
}

У статті здійснено дослідження патріотизму студентів в університеті. 3 иією метою використано адаптований варіанта анкети "Патріот", запитання якої умовно можна розділити на дві групи. Перша передбачала з'ясування розуміння студентами поняття “патріотизм”, його ознак, індивідуальнопсихологічних характеристик і життєвих иінностей людини-патріота тощо. Друга група запитань була спрямована на виявлення активності респондентів у позааудиторній діяльності та форм і методів виховноі роботи в аспекті формування патріотизму. Студентами названі заходи, активними учасниками яких вони виявили бажання бути.

Ключові слова: патріотизм; патріотичне виховання; дослідження патріотизму; студент; університет.

Табл. 3. Літ. 5.

Oksana Vasiuk, Doctor of Sciences (Pedagogy), Associate Professor, Professor of the Pedagogy Department National University of Life and Environmental Sciences of Ukraine Svitlana Vyhovska, Ph.D.(Pedagogy), Associate Professor of the Pedagogy Department National University of Life and Environmental Sciences of Ukraine

Andriy Zvyahelskiy, Master Student

National University of Life and Environmental Sciences of Ukraine

\section{THE RESEARCH OF PATRIOTISM IN YOUNG STUDENTS}

The article examines the students' patriotism at the university. Thus for this purpose, an adapted version of the "Patriot" questionnaire is used, the question of which can be divided into two groups. The first provided for an understanding of students' understanding of the concept "patriotism", its characteristics, individual psychological characteristics and life values of man-patriot, and others like that. It is revealed that the overwhelming majority of students understand the concept "patriotism" and the quality that a citizen-patriot of Ukraine should possess. Among the dominant individual-psychological characteristics and life values of man are selected: "love (spiritual and physical)", "education (good manners)", "freedom (autonomy, independence in judgments and actions)", "honesty (truthfulness, sincerity)", "cleanliness" and "beauty of nature and art". At the same time, the students" answers to the questions allowed us to reveal the non-established final citizenship and life position of student youth.

After all, they received a low rating of such individual psychological characteristics and vital values of a person as: "irreconcilability to the shortcomings of himself and others", "public recognition", "material maintenance of life", "active-active" life. The second group of questions was aimed at revealing the respondents' activity in extracurricular work and the forms and methods of educational work in the aspect of patriotism formation. It was established that students are active participants in the activities of civil-patriotic education and the wishes of further educational work in this aspect, in particular, the student youth expressed desire to take part in lectures and practical classes devoted to the country's sharp political issues; patriotic conversations; conferences; embroidery days; Ukrainian song concerts; volunteers Key actions; meetings with active military personnel, visiting exhibitions, museums and so on. Especially students emphasize the use of educational activities in the educational direction educational activities.

Keywords: patriotism; patriotic upbringing; research of patriotism; a student; a university.

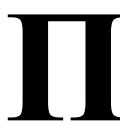
остановка проблеми. Дослідження патріотизму в студентської молоді передусім продиктовано важливою для українського суспільства проблемою формування духовної, високоморальної особистості - громадянина-патріота України, що обумовлюється складною соціальною ситуацією в Україні, перетвореннями в політичному, суспільному, економічному житті та переоцінкою цінностей особистості.

У Концепції національно-патріотичного виховання дітей та молоді наголошується, що 
інтеграційні процеси, що нині відбуваються в Україні, пробудження громадської і громадянської ініціативи, поширення різних громадських рухів, волонтерської діяльності, відбуваються в ситуації підвищеного інтересу і прояву патріотичних почуттів [5].

Отже, перед університетами одним із стрижневих постає завдання виховання патріотизму в студентів, що відповідає викликам сучасності та $є$ складником світогляду особистості, почуттям і базовою якістю особистості, проявом нових ставлень до історії, традицій і звичаїв, культури, релігії українського народу.

Аналіз останніх досліджень і публікацій. Виконано низку дисертаційних досліджень із проблем патріотичного виховання (Т. Гавлітіна, В. Мірошніченко, С. Оришко, Р. Петронговський, М. Тимчик та ін.), що присвячені вихованню патріотизму в загальноосвітніх закладах освіти. Над проблемою формуванню патріотичних якостей особистості студентів закладів вищої освіти працювали О. Абрамчук, О. Гевко, О. Жаровська, М. Коба, А. Максютов, С. Ніколаєнко, Г. Петрів, О. Рацул, І. Сопівник, Р. Сопівник, О. Стьопіна, В. Шинкарук та ін.

Метою статті $є$ дослідження патріотизму студентів в університеті.

Виклад основного матеріалу. Дослідники I. Бех та Н. Чорна розглядають патріотизм як суспільну та індивідуальну цінність, компонент структури особистості. Патріотизм - це, передусім, любов до Батьківщини, до свого народу, турбота про його благо, сприяння утвердженню і становленню України як суверенної, демократичної, правової, соціальної держави, готовність відстоювати ії̈ незалежність, служити їй та захищати їі, розділити свою долю 3 долею Батьківщини [1;2].

На думку М. Боришевського, патріотизм є цінністю, що втілюється в самовідданій любові до рідного народу та землі, Батьківщини, а особистість-патріот уболіває за долю Вітчизни, відчуває потребу віддавати власні сили служінню співвітчизникам і своїй нації [3, 202].

Із метою дослідження патріотизму молоді в університеті нами було опитано студентів Національного університету біоресурсів і природокористування України. Опитування здійснювалося за допомогою адаптованого варіанта анкети "Патріот" [4]. Відповідали на запропоновані запитання 72 респонденти. Розкриємо більш детально результати нашого дослідження.

На перше запитання анкети “Чи вважаєте ви себе патріотом?” були отримані такі відповіді. Стверджувальну відповідь “так” дали 42 студенти, що складає 58 \% загальної кількості опитаних. 21 респондент (29 \%) вважає, що вони патріотами є “частково". 8 студентів (11\%) не вважають, що вони патріоти своєї країни. І лише один студент написав, що “не знає”, чи є він патріотом. На нашу думку, такі відповіді свідчать про те, що студенти підійшли досить критично до оцінки своїх якостей особистості.

Наступним було таке запитання “Які суб' $є к m u$, на Вашу думку, найбільше вплинули на формування Ваших патріотичних поглядів?". Пропонувалися такі варіанти відповіді: “заклад освіти”; “оточуючі люди, друзі”; “батьки”; “органи влади”; “ЗМІ”. Найчастіше студенти називали варіант “оточуючі люди, друзі”. Цей суб’єкт ними обрано 40 разів. Друге місце за виборами респондентів посів суб'єкт “батьки”: його вказали 30 разів. Третє місце за суб'єктом “'ЗМІ” (обраний студентами 16 разів). Найменше виборів студентів припало на такі суб'єкти, як “заклад освіти” та “органи влади” (названі студентами по 8 разів). Отже, найбільший вплив на формування патріотичної вихованості студентів мають оточуючі люди, друзі та батьки, дещо менший - ЗМІ. Такий вибір суб'єкта пояснюємо тим, що в опитування взяли участь студенти-першокурсники, тому на формування їхніх патріотичних поглядів звичайно найбільший вплив мають оточуючі люди, друзі, батьки. Результати опитування ми врахуємо при розробці авторської методики формування патріотизму.

На питання “Що Ви розумієте під поняттям “nатріотизм”? отримано такі відповіді: “любов до своєї держави, народу”, “любов до своєї Батьківщини, виражена у вчинках", “повага до свого народу, праця для нього”, “відданість своїй Батьківщині”, “сприяння покращенню життя у своїй країні”, “бажання змін на краще у своїй країні”, “бережливе ставлення до мови, культури, традицій, законів своєї країни”, “небайдужість до майбутнього своєї країни”, “чесність кожного по відношенню до країни, народу”, “готовність пожертвувати життям заради Батьківщини”, “вірність своїй країні”, “всебічна підтримка політики в державі”, “бажання змінити себе заради покращення життя у країні”, “самовідданість”, “готовність пожертвувати своїми інтересами заради Батьківщини”, “любов, повага до рідної землі”, “гордість за свою Батьківщину, бажання захищати ї” тощо. Зауважимо, що найчастіше студентами називалася теза “любов до своєї Батьківщини". Отже, такі відповіді студентів свідчать про правильне розуміння ними поняття "патріотизм". 
Таблиця 1.

Індивідуально-психологічні характеристики і життєві цінності людини

\begin{tabular}{|c|c|}
\hline $\begin{array}{c}\text { № } \\
\text { П/II }\end{array}$ & Індивідуально-психологічні характеристики і життсві цінності людини \\
\hline 1. & Активне діяльне життя. \\
\hline 2. & Життєва мудрість. \\
\hline 3. & Здоров'я (фізичне і психічне). \\
\hline 4. & Цікава робота. \\
\hline 5. & Краса природи і мистецтва. \\
\hline 6. & Любов (духовна і фізична). \\
\hline 7. & Матеріальне забезпечення життя. \\
\hline 8. & Наявність добрих і вірних друзів. \\
\hline 9. & Суспільне визнання. \\
\hline 10. & Пізнання (освіта, кругозір). \\
\hline 11. & Продуктивне життя. \\
\hline 12. & Розвиток (постійне духовне і фізичне вдосконалення). \\
\hline 13. & Розваги. \\
\hline 14. & Свобода (самостійність, незалежність у судження і вчинках). \\
\hline 15. & Щасливе сімейне життя. \\
\hline 16. & Щастя інших (добробут, розвиток і вдосконалення інших людей, всього народу, людства в цілому). \\
\hline 17. & Творчість (можливість творчої діяльності). \\
\hline 18. & Впевненість у собі (внутрішня гармонія, свобода від внутрішніх протиріч). \\
\hline 19. & Охайність. \\
\hline 20. & Вихованість (гарні манери). \\
\hline 21. & Високі запити (високі вимоги до життя). \\
\hline 22. & Життєрадісність. \\
\hline 23. & Старанність. \\
\hline 24. & Незалежність. \\
\hline 25. & Непримиримість до недоліків у себе та інших. \\
\hline 26. & Освіченість. \\
\hline 27. & Відповідальність (почуття обов'язку, вміння тримати слово). \\
\hline 28. & Раціоналізм (вміння розумно і логічно мислити, приймати обдумані раціональні рішення). \\
\hline 29. & Самоконтроль (стриманість, самодисципліна). \\
\hline 30. & Сміливість у відстоюванні своєї думки, своїх поглядів. \\
\hline 31. & Тверда воля (вміння наполягти на своєму, не відступати перед труднощами). \\
\hline 32. & Терпимість (до поглядів і думки інших, вміння прощати іншим їх помилки). \\
\hline 33. & Широта поглядів (вміння зрозуміти іншу точку зору, поважати інші смаки, звичаї, звички). \\
\hline 34. & Чесність (правдивість, щирість). \\
\hline 35. & Ефективність у справах (працьовитість, продуктивність у роботі) \\
\hline 36. & Чуйність (турботливість). \\
\hline
\end{tabular}

На наступне запитання, "За якими ознаками чи висловлюваннями Ви визначаєте для себе поняття “патріотизм”?”, ми отримали такі результати:

1. Національна самосвідомість, гордість за належність до своєї нації, народу - 26 виборів;
2. Непримиримість до представників інших націй і народів - 4 вибори;

3. Інтернаціоналізм, готовність до співпраці 3 представниками інших націй і народів у інтересах своєї країни - 12 виборів;

4. Безкорислива любов і служіння Батьківщині, 


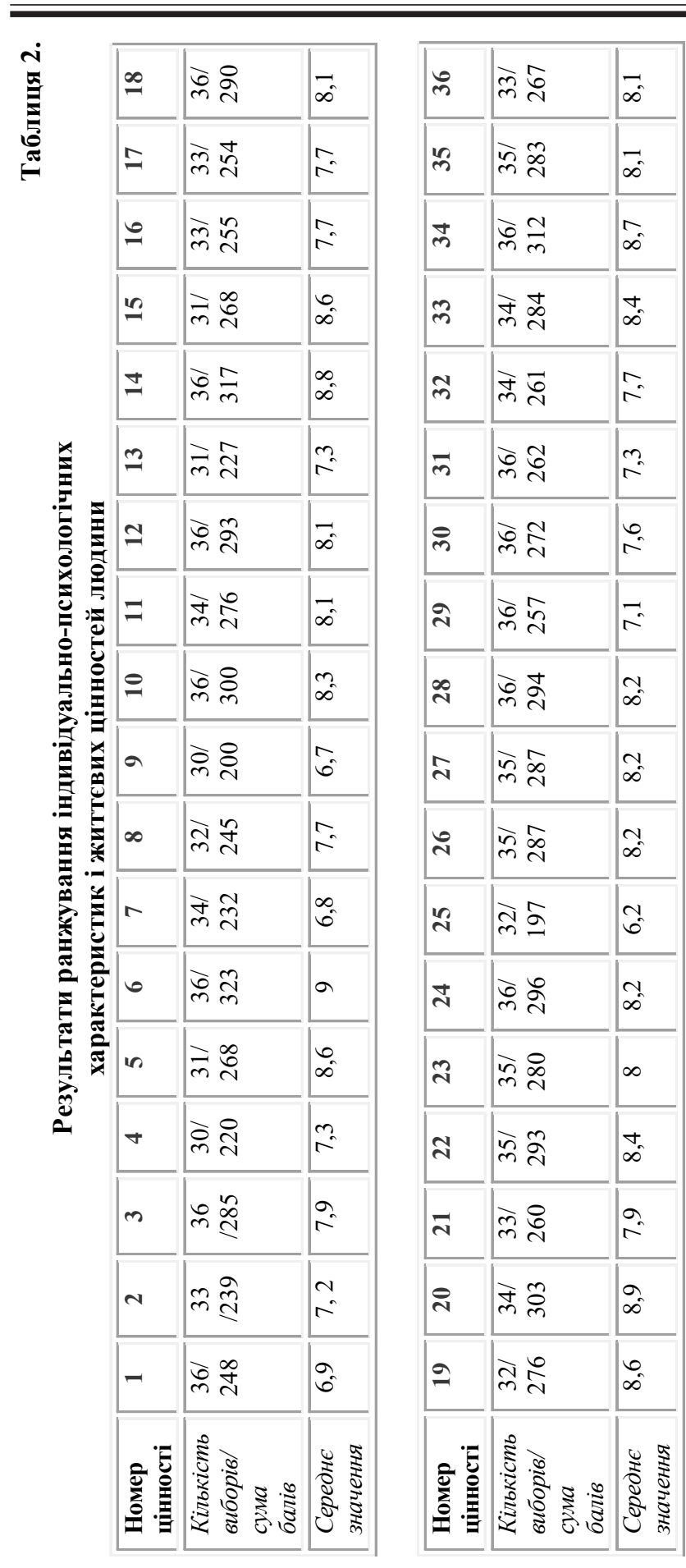

7. Патріотизм нині не актуальний, не сучасний, не для сучасної молоді -4 вибори.

8. Патріотизм це лише романтичний образ, літературна вигадка - не обрали жодного разу.

Таким чином, найбільшого значення студентами надається таким ознакам патріотизму, як любов до рідного дому, країни, міста, вірність національній культурі, традиціям, устрою життя; спроба працювати для процвітання України, для того, щоб держава, в якій вони живуть, була авторитетною, міцною і шанованою у світ; національна самосвідомість, гордість за належність до своєї нації, народу. Незначна кількість студентів вказали такі ознаки: патріотизм нині не актуальний, не сучасний, не для сучасної молоді; непримиримість до представників інших націй і народів.

На п'яте запитання “Якщчо Ви не змогли визначити для себе поняття “патріотизм”, то в чому причина Вашого нерозуміння?” студенти відповіли таким чином: “немає бажання" обрали 4 особи, "немає можливості" вказали 3 опитаних, “вважаю це неактуальним“ зазначили 5 осіб, що свідчить, на нашу думку, про вплив суб'єктивних чинників під час опитування студентів. Адже студенти 3 відповіддю на попереднє запитання не мали труднощів.

Наступне запитання було таким: “Перед Вами список індивідуально-психологічних характеристик $і$ життєвих цінностей людини (таблиця 1). Визначте за 10бальною шкалою, на скільки иі якості й цінності сформовані у Вас". Зауважимо, що 1 бал відповідає мінімальній значущості цінності, що сформована у студентів, а 10 балів максимальній. При обробці результатів анкети ми підрахували сумарне значення цінності по всій обстежуваній виборці та визначили ії середнє значення.

У таблиці 2 наведено кількісні показники, зокрема сумарне значення

готовність до самопожертви заради її блага або спасіння - 10 виборів;

5. Любов до рідного дому, країни, міста, вірність національній культурі, традиціям, устрою життя - 40 виборів;

6. Спроба працювати для процвітання України, для того, щоб держава, в якій Ви живете, була авторитетною, міцною і шанованою у світ - 32 вибори; цінності по всій обстежуваній виборці та її середнє значення.

Із таблиці 2 зрозуміло, що для студентів домінантними $є$ наступні індивідуальнопсихологічні характеристики і життєві цінності людини: “любов (духовна і фізична)” (середнє значення 9), “вихованість (гарні манери)” (середнє значення 8,9), “свобода (самостійність, незалежність у судженнях і вчинках)” (середнє 


\section{ДОСЛЬЖЖЕНЯ ПАТРІОТИЗМУ В СТУДЕНТСЬКОЇ МОЛОДІ}

значення 8,8), “чесність (правдивість, щирість)" (середнє значення 8,7), “охайність” та “краса природи і мистецтва” (середнє значення 8,6). Вибір студентами цих якостей не викликає в нас жодних сумнівів, адже для юнацького віку вони $\epsilon$ головними.

Отримали низьку оцінку такі індивідуальнопсихологічні характеристики і життєві цінності людини, як: “непримиримість до недоліків у себе та інших” (середнє значення 6,2), “суспільне визнання" (середнє значення 6,7), “матеріальне забезпечення життя” (середнє значення 6,8), “активне діяльне життя” (середнє значення 6,9). Отже, відповіді студентів містять певні протиріччя. На нашу думку, це можна пояснити остаточно не сформованою громадянською позицією.

Результати наступного запитання "Bidмітьте, щуо y Вашій компаніі, колективі, колі Ваших знайомих цінується більше?" відображено у таблиці 3. розуміння ними особистісних цінностей сучасної української молоді.

Восьмим запитанням ми сформулювали студентам таке: "Із запропонованих варіантів відповідей виберіть ту, яка найбільшою мірою виражає Вашу точку зору". Варіантами відповіді на запитання були наступні: “Я люблю, коли інші люди мене цінують”, “Я відчуваю задоволення від добре виконаної роботи”, “Я люблю приємно проводити час із друзями”. Перший варіант відповіді обрали 25 \% студентів (18 осіб), другий - 56 \% (40 осіб), третій - $19 \%$ (14 осіб). Отже, переважна більшість студентів має правильно сформовану життєву позицію.

Далі студентська молодь мала закінчити речення: “Бути гідним громадянином своєї країни означає бути...”. Варіанти відповідей були такими: “любити свою країну, сприяти іiі розвитку”,“патріотом”,“слідувати законам, бути активним громадянином”, “поводити себе як

Таблиця 3.

Колективні цінності

\begin{tabular}{|c|c|c|}
\hline $\begin{array}{l}\text { Номер } \\
\text { п/II }\end{array}$ & Цінності & $\begin{array}{c}\text { Кількість } \\
\text { виборів }\end{array}$ \\
\hline 1 & Вміння цінувати справжню дружбу. & 38 \\
\hline 2 & Готовність допомогти один одному в складний час. & 58 \\
\hline 3 & Взаєморозуміння. & 62 \\
\hline 4 & Чесність, порядність, принциповість. & 58 \\
\hline 5 & Приємна зовнішність. & 14 \\
\hline 6 & Гарні манери. & 30 \\
\hline 7 & Вміння модно одягатися. & 2 \\
\hline 8 & Сила волі. & 28 \\
\hline 9 & Сміливість. & 22 \\
\hline 10 & Рішучість. & 40 \\
\hline 11 & Інтерес, знання літератури, мистецтва, музики. & 26 \\
\hline 12 & Інтерес до політики. & 4 \\
\hline 13 & Наявність фірмових речей тощо. & 4 \\
\hline 14 & Наявність грошей на різні витрати. & 14 \\
\hline 15 & Здібності. & 34 \\
\hline
\end{tabular}

Як видно з таблиці 3, респонденти у спілкуванні 3 друзями та у студентському товаристві найбільше цінують такі риси особистості як: взаєморозуміння (62 вибір), готовність допомогти один одному в складний час та чесність, порядність, принциповість (по 58 виборів), рішучість (40 виборів), здібності (34 виборів). Найменше обирали опитані такі риси: вміння модно одягатися (2 вибір), інтерес до політики та наявність фірмових речей (по 4 вибори), приємна зовнішність та наявність грошей на різні витрати (по 14 виборів), що демонструє правильне справжній громадянин України, щоб потім не було соромно за свої вчинки”, “сильною та відповідальною за свої вчинки людиною 3 сформованими цінностями та активною життєвою позицією”, “освіченим та толерантним”, “корисним Батьківщині”, “гідною Людиною”, “чесним і порядним”, “відповідальним”, “свідомим громадянином”, “поважати та захищати інтереси Батьківщини”, “бути свідомим свого обов'язку перед нею” тощо.

Відповіді на запитання "Ваше ставлення до nодій у листопадi 2013 p.” розподілилися таким 
чином: 37 осіб (52 \%) відповіли “Не знаю”, 27 осіб (37 \%) - “Дуже хотілося б бути у центрі тих подій, але не було можливості”, 5 осіб (7\%) - “Брав безпосередню участь у цих подіях" і ще 3 особи (4 \%) відповіли, що “Мені байдуже”. Такі відповіді студентів ми пояснюємо тим, що в 2013 р. вони ще були школярами, а отже не до кінця розуміли того, що відбувалося на Майдані в 2013 р. До того ж, більшість із них не проживали в м. Києві й не могли бути в центрі подій.

Єдність думок продемонстрували студенти, відповідаючи на наступне запитання : "Ваше ставлення до подій на Сході Украӥни”. Не ставиться позитивно до подій на Сході України жоден опитаний нами студент. Негативне ставлення висловили 66 респондентів (91\%), ще 6 осіб (9 \%) не визначилися зі своєю позицією щодо подій на Сході України.

Відповідаючи на запитання нашої анкети “ $Я к i$ заходи проводяться в університеті щзодо формування патріотизму?", опитані студенти вказали бесіди; дні пам'яті; зустрічі з воїнами Другої світової війни та АТО; конференції, присвячені відомим українцям; різного роду мистецькі заходи; Дні відкритих дверей на військовій кафедрі; екскурсії; вечори пам'яті; науково-практичні конференції, що присвячені видатним людям України тощо.

На наступне запитання анкети "Чи берете Вu участь в університетських заходах патріотичного та громадянського спрямування?" переважна більшість опитаних (52, тобто 81 \%) відповіли, що "Так”. "Нi” вказали 14 осіб (19\%).

Наступним було запитання "Які заходи громадянського спрямування Ви хотіли б, щзоб проводилися у Вашому закладі вищої освіти?". Серед заходів патріотичного виховання студенти назвали лекційні та практичні заняття, присвячені гострим політичним питанням країни; бесіди патріотичного спрямування; конференції; продовжувати святкувати День вишиванки; проводити концерти української пісні; виставки; відвідування музеїв; волонтерські акції; зустрічі 3 діючими військовими. Особливо студенти наголошувати на використанні у виховній роботі цікавих форм і методів.

Відповіді студентів на запитання "На Ваму думку, чи сприяе спорт та різного роду спортивні змагання формуванню патріотизму $y$ молодi?" в переважній більшості були стверджувальними. “Так” вказали у своїх анкетах 60 (83 \%) респондентів, "Нi” - 7 (10\%) та ще 5 (7 \%) - “Частково". Отже, розробляючи методику формування патріотизму, ми врахуємо побажання студентів щодо проведення конкретних виховних заходів, зокрема запропонуємо різного роду спортивні заходи.

Наступне, про що ми хотіли довідатись, то це про заходи, які, на думку студентської молод $i$, сприятимуть вихованню патріотизму та учасником яких вони хотіли б стати. Респондентами названі такі: вечори пам'яті; зустрічі 3 відомими людьми та ветеранами війн; заходи присвячені козацтву; заходи з використанням інноваційних форм і методів патріотичного спрямування; волонтерські акції; заходи, в яких буде використана усна народна творчість, звучатиме українська пісня; спортивні заходи; олімпіади 3 навчальних дисциплін соціально-гуманітарного спрямування; перегляд кінофільмів; акції патріотично-громадянської спрямованості; конкурси патріотичної пісні; екскурсії тощо.

Висновки. Здійснено опитування студентів університету за допомогою анкети “Патріот”. Це дозволило дійти таких висновків. Переважна більшість студентів розуміє поняття "патріотизм" та якості, якими має володіти громадянин-патріот України. Проте кожен із них вкладає у поняття свій набір індивідуально-психологічних характеристик і життєвих цінностей людини. Водночас, відповіді студентів на запитання дозволили нам виявити остаточно не сформовану громадянську та життєву позицію студентської молоді. Також 3'ясовано, що студенти є активними учасниками заходів громадянськопатріотичного виховання, та їхні побажання щодо подальшої виховної роботи у цьому аспекті.

\section{ЛІТЕРАТУРА}

1. Бех І., Чорна К. Духовні цінності в розвитку особистості. Педагогіка і психологія. 1997. №1. C. $124-129$.

2. Бех I., Чорна К. Національна ідея в становленні громадянина-патріота України. Київ. 2014. 48 c.

3. Боришевський М. Й. Національна самосвідомість особистості: сутність та шляхи становлення. Система виховання національної самосвідомості учнів загальноосвітньої школи. Київ, 1999. С. 189 219.

4. Жаровська О. П. Патріотичне виховання студентів в освітньо-виховному середовищі педагогічного університету : дис. ... канд.. пед.. наук : 13.00.07. Вінниця, 2015. 290 с.

5. Концепція національно-патріотичного виховання дітей та молоді. URL : https:// zakon.rada.gov.ua/rada/show/v0641729-15?lang=en

\section{REFERENCES}

1. Bekh, I. \& Chorn, K. (1997). Dukhovni tsinnosti 
v rozvytku osobystosti [The dpiritual values in the development of personality]. "Pedagogy and psychology”. Vol. 1. pp. 124-129. [in Ukrainian].

2. Bekh, I. \& Chorna, K. (2014). Natsionalna ideia $\mathrm{v}$ stanovlenni hromadianyna-patriota Ukrainy [National idea of becoming a citizen-patriot of Ukraine]. Kyiv, 48 p. [in Ukrainian].

3. Boryshevskyi, M. Y. (1999). Natsionalna samosvidomist osobystosti: sutnist ta shliakhy stanovlennia [National identity of an individual: the nature and ways of becoming]. System of education of national consciousness of pupils of a secondary school. Kyiv, 1999. pp. 189-219. [in Ukrainian].
4. Zharovska, O. P. (2015). Patriotychne vykhovannia studentiv v osvitno-vykhovnomu seredovyshchi pedahohichnoho universytetu [Patriotic education of students in the educational and educational environment of the pedagogical university]. Candidate's thesis. Vinnytsia, 290 p. [in Ukrainian].

5. Kontseptsiia natsionalno-patriotychnoho vykhovannia ditei ta molod [The concept of national patriotic education of children and youth]. Available at: https://zakon.rada.gov.ua/rada/show/v064172915?lang=en (Accessed 14 July. 2019). [in Ukrainian].

Стаття надійшла до редакції 24.07.2019

\section{УДК 738 \\ DOI:}

Валентина Лозовецька, доктор педагогічних наук, професор, професор кафедри теорії $i$ методики технологічної освіти, креслення та компютерної графіки Національного педагогічного університету імені М.П. Драгоманова, м. Київ

\section{ФАКТОРИ ТА ПРОБЛЕМИ, ЩО ВПЛИВАЮТЬ НА КАР'СРНИЙ РОЗВИТОК СУЧАСНӦ̈ ОСОБИСТОСТІ}

Стаття присвячена проблемам кар'єрного розвитку особистості в умовах сучасного ринку прачі щзодо врахування результатів соціально-економічних змін, побудови відкритого суспільства знань, його системного професійного саморозвитку. Акиентується увага на тому, щуо кар'єрний розвиток сучасної особистості в умовах ринкової економіки засвідчив низку проблем щзодо професійної активності. Це, передусім: не володіння достатнім рівнем знань про сутність ринкових відносин, ринкові цінності, сучасний ринок праці, правила поведінки на ринку праці; переважають ідеалістичні уявлення про майбутню професію, професійну діяльність та кар 'єру; відчуття невпевненості у подальшій трудовій діяльності; не готовність конкурувати і бути суб 'єктом на ринку прачі; незацікавленість обраною сферою діяльності; низький рівень професійної активності; відсутність конкретних і узагальнених иілей щодо реалізації особистісних $i$ професійних планів; неузгодженість особистісних цілей з цілями організації; неадекватна самооиінка тощо.

Ключові слова: кар 'єрний розвиток; кар'єра; сочіально-економічні зміни; особистість; ринок праці; ринкова економіка; конкуренція.

Jim. 11.

Valentyna Lozovetska, Doctor of Sciences (Pedagogy), Professor, Professor of the Theory and Methods of Technological Education, Drawings and Computer Graphics Department Mykhaylo Drahomanov National Pedagogical University, Kyiv

\section{FACTORS AND PROBLEMS, THAT INFLUENCE ON THE CAREER DEVELOPMENT OF MODERN PERSONALITY}

The article is dedicated to problems of career development of the individual in the modern labor market conditions, with regard to consideration results of socio-economic changes, building an open-knowledge society, its systemic professional self-development. The main idea is that the career development of current personality in circumstances of economy market, has shown problems with professional activity. This is, first of all: not having a sufficient level of knowledge about the essence of market relations, market values, modern labor market, rules of behavior in the labor market; idealistic ideas about future profession, professional activity and career prevail; feeling insecure about further work; not willingness to compete and be a subject in the labor market; disinterestedness of the chosen sphere of activity; low level of professional activity; lack of specific and general goals for the implementation of personal and professional plans; inconsistency of personal goals with the goals of the organization; inadequate self-esteem, etc. Market conditions have also changed circumstances in the field of employment, now it has a temporary nature of contracts, lack of guarantees, unpredictability, self-control and self-management of their careers. In this case, the career does not begin from the moment of appointment to any position, but from the moment of choosing the sphere in which you can apply your opportunities, which requires substantiation of the relevant 